\author{
Katarzyna Hanas \\ Maria Curie-Skłodowska University in Lublin, Poland \\ ORCID: 0000-0001-9480-9107 \\ katarzyna.hanas@poczta.umcs.lublin.pl
}

\title{
Interpretative Discretion of Judiciary and the Well-Being of the Child*
}

\author{
Interpretacyjna dyskrecjonalność sędziowska a dobro dziecka
}

\author{
SUMMARY
}

The well-being of the child is a common criterion in many Polish normative regulations pertaining to different branches of law. It is both a tool for the law-making and the executive bodies, employed to direct the law-applying bodies towards ensuring full protection of the child. This article is focused on analysing interpretative judicial discretion with respect to the well-being of the child as manifested in the judicial decisions of the Supreme Court and in the judgements of the Supreme Administrative Court and Constitutional Tribunal. In the course of the research, the author undertakes to determine the essence of interpretative judicial discretion in cases predominantly focused on establishing the current and postulated situation of the child with a view to ensuring the most favourable ruling for the same.

Keywords: interpretative discretion of judiciary; the well-being of the child; extra-legal axiology

\section{INTRODUCTION}

"The well-being of the child" is an inter-branch construct in the legal system. It is also an interdisciplinary value, rooted as it is in sociology, psychology, philosophy, etc. The criterion of said well-being constitutes a tool applicable to both

* The paper has been prepared as a part of the research grant, entitled "The normative construct 'the good of the child' and its judicial application" (UMO-2017/25/N/HS5/01692), financed by Narodowe Centrum Nauki (National Science Center, Poland).

1 In the paper, I refer to the construct of "the well-being of the child" functioning within the framework of the 1989 United Nations Convention on Rights of the Child as the most adequate counterpart of the Polish expression ("the good of the child"). Given the certain terminological 
law-makers, who direct their interpretative inference towards ensuring the full personal protection of the child, and the law-applying bodies alike. The criterion may be included as an element of legal principles or general reference clauses. It should be mentioned that the framework of the legal system includes normative acts wherein: a) the normative construct of "the well-being of the child" is an apparent element of the legal provision; b) the well-being of the child is not included in the wording of the normative construct but the linguistic context of the normative act indicates consideration of specific extra-legal values ${ }^{2}$ that need to be taken into account in the evaluation of the child's situation; c) there are other constructs whose semantic scope is, to an extent, similar to that of "the well-being of the child", e.g. "the well-being of the student", "the well-being of the minor". As such, the well-being of the child is not defined in normative acts, which means that the burden of determining its meaning lies, each time, with the entity applying the law. At the same time, judicial authorities look for definitions already formulated by legal science experts ${ }^{3}$.

The main focus of this paper is on the issue of interpretative discretion of judges ${ }^{4}$ considered with reference to an analysis of the Supreme Court, Supreme Administrative Court, and Constitutional Tribunal case law in the context of the well-being of the child. With regard to the concept of discretionary powers, one could cite the definition proposed by J. Stelmach who refers to the dictionary explanation to indicate that judicial discretion ought to be understood as "(the judge's) ability to assume the legal character of norms (principles) other than previously identified as

inconsistency and the parallel use in the text of the Convention of the construct "the welfare of the child", I assume that the latter ought to be applied in the context of judicial decisions as a reference to the child's material prosperity. A short explanation is also warranted for my use of the concepts of normative construct and criterion. I understand a normative construct, after L. Leszczyński, as a construct "which is clearly provided in the text of a legal act (law) and whereby the law-maker correlates with norms, addressees the principles of accounting for extra-legal criteria in decisions regarding the application of law or »compliance« therewith" (L. Leszczyński, Stosowanie generalnych klauzul odsyłających, Kraków 2001, p. 22). A criterion, also referred to in the paper as an extra-legal criterion, is a legally undefined category. Cf. ibidem.

2 Judicial authorities often adopt the premise that the well-being of the child constitutes a value. See, e.g., judgement of the Constitutional Tribunal of 26 November 2013, P 33/12, Legalis 740186.

3 Example definitions can be found in: J. Marciniak, Treść i sprawowanie opieki nad matoletnim, Warszawa 1975, p. 10; W. Stojanowska, Dobro dziecka w aspekcie sprawowania nad nim władzy rodzicielskiej, „Studia nad Rodziną” 2000, nr 4/1(6), p. 55; S. Kołodziejski, Dobro wspólnych małoletnich dzieci jako przesłanka odmowy orzeczenia rozwodu, „Palestra” 1965, nr 9, p. 30; T. Żyznowski, [in:] Kodeks postępowania cywilnego, t. 2: Komentarz. Art. 367-729, red. A. Marciniak, K. Piasecki, Warszawa 2016, p. 824.

4 Some of the most important publications on the subject of judicial discretion include: Dyskrecjonalność w prawie, red. W. Staśkiewicz, T. Stawecki, Warszawa 2010; B. Wojciechowski, Dyskrecjonalność sędziowska. Studium teoretycznoprawne, Toruń 2004; D.J. Galligan, Discretionary Powers. A Legal Study of Official Discretion, New York 2011. 
legal". The author analyzes the concept of judicial discretion based on the positivist and non-positivist concepts of law ${ }^{5}$. In turn, A. Kozak analyzes discretionary powers from the external ("political") and internal ("legal") perspective, the latter of which is directly related to judicial ruling and pertains to the approach adopted by the authority competent to interpret legal texts and issue decisions ${ }^{6}$. B. Wojciechowski argues that a narrow or broad perspective can be adopted when discussing judicial discretion. The narrow approach pertains to the freedom of choosing alternatively formulated legal consequences whereas the broad approach entails a certain thought process, assessment of facts, interpretation of legal norms, determination of mutual correlations between the same, and at times also actual law-making ${ }^{7}$.

The aim of this article is to discuss the impact of the child's well-being on judicial discretion and the ways in which said discretion can be exercised. It is noteworthy that courts can take advantage of a relatively broad spectrum thereof when adopting the aforementioned criterion. Said scope is determined by law-givers and stems from the character of the criterion itself, which may be associated with the question of legal vs extra-legal axiology.

\section{THE CRITERION OF THE WELL-BEING OF THE CHILD AS AN ELEMENT OF A GENERAL REFERENCE CLAUSE}

The well-being of the child may be treated as a directive, assumption, goal, value, premise, or exception ${ }^{8}$. The way in which said well-being is classified strongly suggests the existence of interpretative judicial discretion ${ }^{9}$. Moreover, the character of this criterion is somewhat peculiar as it adapts itself to its normative environment due to such properties of the expression as its indefiniteness. The wording is also distinctly abstract, which determines "the qualification of a given phenomenon or state as cor-

5 J. Stelmach, Dyskrecjonalność sędziowska w pozytywistycznych i niepozytywistycznych koncepcjach prawa, [in:] Dyskrecjonalność w prawie..., p. 54.

6 A. Kozak, Dylematy prawniczej dyskrecjonalności. Między ideologia polityki a teoria prawa, [in:] Dyskrecjonalność w prawie..., p. $59 \mathrm{ff}$.

7 B. Wojciechowski, op. cit., pp. 16-17 and 66.

8 The meanings of each of those terms are demonstrably different. See Stownik języka polskiego, t. 1: $A-K$, red. M. Szymczak, Warszawa 1978, p. 235, 487; Stownik języka polskiego, t. 2: $L-P$, red. M. Szymczak, Warszawa 1979, p. 1006; Stownik języka polskiego, t. 3: $R-\dot{Z}$, red. M. Szymczak, Warszawa 1981, p. 660, 924.

9 With regard to the criterion of the well-being of the child, or more specifically the principle of protecting the same, the term "directive" is most often applied. See, e.g., judgement of the Supreme Court - Criminal Division of 18 April 2013, SNO 6/13, Legalis 797136; resolution of the Supreme Court - Civil Division of 8 March 2006, III CZP 98/05, Legalis 73542; resolution of the Supreme Court - Civil Division of 24 February 2011, III CZP 137/10, Legalis 287414. 
responding to the wording of the given name" ${ }^{10}$. Hence, the concept itself is difficult to define and requires case-by-case interpretation with due consideration for the facts established in the given matter. Some semantic hints may be found in the fact that well-being is overall a desirable, positive value which applies personally to the child. Therefore, the criterion ought to be construed through the prism of rights, dignity, individual safety and social status subject to protection, due to the minor or underage person's susceptibility, lack of life experience, and still developing worldview.

As follows from the conducted analysis, in Polish law, judicial discretion with regard to determining the child's situation is a consequence of:

- introduction of the normative construct "the well-being of the child" as well as other similar constructs such as "the well-being of the student", "the well-being of children in a family", or "the well-being of the minor" in the wording of legislative provisions,

- introduction of the normative construct "the best interest of the child" in the wording of legislative provisions,

- judicial application of the provisions of international law which refer to constructs such as "the well-being of the child", "the best interest of the child", "the welfare of the child", as well as other related constructs,

- inclusion in the wording of legislative provisions of constructs similar to "the well-being of the child" whose semantic scope includes references to the value of the child's well-being.

Judicial discretionary powers are largely dependent on legislative intentions and the diversity of general reference clauses introduced in a normative text. Interpretation may be based solely on the criterion of well-being ${ }^{11}$ or account for two or more extra-legal criteria ${ }^{12}$, e.g. the well-being of the child and public interest. In the latter case, the understanding of the expression will depend on the mutual correlations that may exist between the two criteria. For instance, the obligation to inoculate children is consistent both with the well-being of the child and social interest. In this case, the Supreme Administrative Court evoked the wording of the law specifying the conditions of exercising parental authority ${ }^{13}$. It should be noted that the character of judicial freedom in the context of the child's well-being may influence the ability to refer to other extra-legal criteria, and vice versa. In fact, the criterion of the well-being of the child has a bearing on the determination of legal consequences in the course of the judicial process.

${ }^{10}$ L. Leszczyński, Tworzenie generalnych klauzul odsyłajacych, Lublin 2000, p. 18.

${ }^{11}$ See, e.g., judgement of the Supreme Administrative Court of 22 June 2017, II OSK 2366/16, Legalis 1649542 .

12 See, e.g., judgement of the Supreme Administrative Court of 12 July 2017, II GSK 3611/15, Legalis 1672604.

${ }^{13}$ See L. Leszczyński, Tworzenie generalnych klauzul..., p. 18. 


\section{CRITERION OF THE WELL-BEING OF THE CHILD AS AN ELEMENT OF LEGAL PRINCIPLES}

Legal principles play a particular role in the process of applying the law, primarily in terms of directing the focus of interpretation based on the axiological, functional and hierarchical significance of given principles relative to other standards ${ }^{14}$.

At the level of normative acts, one could identify standards - principles such as the principle of protecting the child's well-being (Family and Guardianship Code ${ }^{15}$ and Article 3.2 of the Convention on the Rights of the Child ${ }^{16}$ ), the principle of protecting the rights of the child (Article 72.1 of the Polish Constitution ${ }^{17}$ ), or the principle of securing the best interest of the child (Article 3.1 of the Convention on the Rights of the Child ${ }^{18}$ ). Within the legal system, said principles correlate with each other to provide a cohesive protective instrument.

The gravity of the interpretative difficulty inherent in the application of legal principle is clearly visible in the context of the extensive output in the fields of legal dogmatics and case law.

It is noteworthy that when adjudicating in cases involving children, courts are increasingly inclined to evoke legal principles, thus incorporating the consideration of the well-being of the child into the judicial process itself. This is also the case when the discussed criterion is not an element per se of the given legal provision. Hence, the well-being of the child treated as a legal principle has a considerable bearing on the entire judicial process, from validation of the legal sources to the substantiation of the decision to apply the given law. A similar situation is observed in terms of the principle of protecting the rights of the child or securing the best interest of the child. In the course of the interpretation, one needs to only identify the law from which a given legal principle originates. A good example illustrating the potency of the discussed criterion is the judgement of the Supreme

${ }^{14}$ Cf. L. Leszczyński, G. Maroń, Pojęcie i treść zasad prawa oraz generalnych klauzul odsyłajacych. Uwagi porównawcze, „Annales UMCS sectio G (Ius)” 2013, Vol. 60(1), p. 81.

15 Act of 25 February 1964 - Family and Guardianship Code (Journal of Laws 2019, item 2086).

${ }^{16}$ Convention on the Rights of the Child of 20 October 1989 (Journal of Laws 1991, No. 120, item 526). Courts commonly evoke Article 3 of the Convention on the Rights of the Child. However, the interpretations tend to derive from the wording of the provision only one principle pertaining to securing the best interest of the child, regardless of the fact that the article conveys two distinct principles, the other one being that of protecting the well-being of the child.

17 Constitution of the Republic of Poland of 2 April 1997 (Journal of Laws 1997, No. 78, item 483).

18 Article 3.1 of the Convention on the Rights of the Child reads: "In all actions concerning children, whether undertaken by public or private social welfare institutions, courts of law, administrative authorities or legislative bodies, the best interests of the child shall be a primary consideration". The cited provision emphasizes the obligation to account for the best interest of the child when applying the law, the wording of the Polish version of the Convention is notably somewhat different. Nonetheless, case law does not seem to evidence a negative impact of this fact on the judicial interpretation of the same. 
Administrative Court of 30 October $2018^{19}$. The facts of the case pertained to the legal status of a child raised by single-sex parents, born from a surrogate mother, whose citizenship rights were acquired by law. The competent Voivode refused to issue the decision awarding Polish citizenship to the child and demanded prior submission of information regarding the child's parents. The decision was subsequently upheld by the minister who evoked the following arguments. Firstly, he emphasized the legal nature of the concept of parenthood under Polish law which does not recognize the institutions of "single-sex parents" or "a surrogate mother", stating furthermore that surrogacy contracts are not valid in the light thereof. Moreover, it was argued that single-sex couples have no parental rights under the laws of Poland. In the opinion of the authority, the birth certificate issued in California failed to specify the actual parents of the child and, therefore, did not comply with relevant Polish legislation. The arguments of said authorities were recognized by the Voivodeship Administrative Court which categorically evoked the public order clause expressed in the text of the Act of 4 February 2011 - International Private Law. In the Court's opinion, the rule of Polish law stipulates that a child can only have two parents (mother - a woman, and father - a man, with the emphasis being on bonds formed biologically or through adoption), as well as that a child cannot constitute the object of a contract that deprives such person of the identity derived from natural parenthood. The subsequent ruling of the Supreme Administrative Court adopted a contrary approach. The Court observed that the issue of primary importance in the relevant case is the fact that "a human being is born with inherent and inalienable dignity, and the right to citizenship if one of the parents is a Polish national". At the same time, the Supreme Administrative Court evoked the criterion of the well-being of the child by citing Article 3.1 of the Convention on the Rights of the Child. The relevant provision refers to the "best interest of the child", nonetheless, one can observe a tendency in case law to refer to the well-being of the child specifically in the context of the legal principle expressed in Article 3.1 of the Convention. This further confirms the fact that the axiological framework of the regulation is based on the discussed criterion.

The example of the aforementioned ruling reveals judicial freedom orientated towards establishing the well-being of the child with respect to the rights of the child and, thus, employing a case approach that considers future legal consequences. Accounting for the criterion of the well-being of the child as the basis of the applicable legal principles in the judicial decision-making process is necessary if the relevant legal interpretation is to be correctly performed.

19 Judgement of the Supreme Administrative Court of 30 October 2018, II OSK 1868/16, Legalis 1860297. 


\section{FOCUS OF DISCRETIONARY POWER}

Judicial discretion is naturally related to the notions of judicial freedom, judicial activism, and judicial independence. In my considered opinion, approaching discretionary powers in the context of the same leads to a rather broad understanding and overall scope thereof. This stems from a variety of reasons and may be conditioned by more than just "discernibility" of the well-being of the child in legal provisions. Discretion with respect to the application of laws pertaining to children is, in a way, a given due to the very nature of cases related thereto. One could conclude that when a case involving a child is adjudicated, particular care must be taken to weight the interests of all participants in the proceedings with due consideration for the discussed criterion.

Judicial discretion is related to the principle of judicial freedom, not to be confused with arbitrariness. Given the above, such discretionary powers should also be considered in terms of informed and experience-based interpretation of law through the application, or more specifically reconstruction, of the relevant normative grounds, taking into account legal norms and normative constructs referring the decision-maker to extra-legal criteria, as well as the actual purpose and intention of the law itself. For instance, observing the existence in a given provision of a reference clause without relating the same to the relevant legal principle may lead to erroneous conclusions and consequently less than accurate interpretation. It is, therefore, not enough to merely "reach" outside the legal system for certain values and interpret legal provisions on this basis, one must also verify one's inference against constitutional and conventional norms-principles as well as, at times, consider the actual purpose of the given regulation. A good example here could be the judgement of the Supreme Court of 31 January $2018^{20}$. The ruling pertains to a decision of a Danish court regarding cancellation of joint parental authority and transfer of the entirety thereof to the minor child's father. The first instance court recognized the foreign judgement concluding that the ruling was not contrary to the child's well-being. However, the Appellate Court deemed this judgement to be inconsistent with the Polish public policy. The Supreme Court elaborated on the argumentation provided by the Appellate Court by stating that "primary public policy principles ought to be understood as fundamental constitutional determinations pertinent to the socioeconomic system and key provisions regulating the respective domains of substantive and procedural law that cannot be automatically equated with the substantive grounds for the application of a civil legal institution". The Court concluded that the well-being of the child constitutes such a principle and

${ }^{20}$ Judgement of the Supreme Court - Civil Division of 31 January 2018, IV CSK 442/17, Legalis 1765977. 
dictates, in the case at hand, that the foreign ruling should not be recognized due to the dominant role of the mother in childrearing.

In terms of limits to judicial discretion, we should consider the prevalent opinion that one ought to account for the actual purpose of the given act, evoke generally applicable values and laws, operate within a particular ideology of judicial practice defined and adopted by the given judicial authority, as well as apply relevant legal principles (including the principles of a democratic state rooted in the rule of law, the postulate of judicial independence, and legal certainty ${ }^{21}$. Notably, the afore ought to be considered primarily in terms of focusing judicial discretion rather than limiting the same, which follows from the already considered differentiation between judicial freedom and arbitrariness. Moreover, the criterion of the well-being of the child sometimes detracts from the formalism ${ }^{22}$ associated with ongoing court proceedings, which further corroborates the thesis that the same cannot be considered a limitation to discretionary powers.

Judicial freedom is affected by the nature of the expression "well-being of the child" which can indeed be interpreted in a variety of ways relative to its contextual character stemming from the consideration of, e.g., other principles, general clauses, framework standards, and specificity of the given branch of law.

The very existence of the criterion of the child's well-being, as manifested in a variety of normative constructs: a) determines the direction of operative interpretations; b) prevents arbitrariness but facilitates freedom of interpretation ${ }^{23}$; c) should not be treated as a limitation by law but rather as guidance for judicial objectivism (which means that judicial discretion is not absolute but rather focused on the criterion of the child's well-being in all cases involving children); d) ought to lead to continuous verification of previous case law and claims made by representatives of legal dogmatics.

When evoking substantiation of court decisions, entities partaking in proceedings rarely refer to the standards-principles conveyed in conventions (e.g. Article 3 of the Convention on the Rights of the Child) or constitutional standards-principles (e.g. Article 72 of the Polish Constitution). When they do, however, the arguments voiced are not always consistent with the correct understanding of the well-being of children, i.e. focused on the facilitation of their development and protection of their rights. At times, situations emerge where courts fail to properly exercise their discretionary powers. Specifically, rather than duly account for the content of

${ }^{21}$ B. Wojciechowski (op. cit., p. 199) argues that the purpose of an act limits judicial discretion due to the fact that the role of the court is to facilitate the realisation of its inherent goal.

${ }^{22}$ See, e.g., judgement of the Supreme Court - Civil Division of 24 November 2016, III CZP 68/16, Legalis 1533167; judgement of the Supreme Court - Civil Division of 24 November 2016, II CA 1/16, Legalis 1565006.

${ }^{23}$ A similar sentiment was voiced by B. Wojciechowski (op. cit., p. $197 \mathrm{ff}$.) who concluded that when exercising one's discretionary powers, a judge must not make random, arbitrary choices. 
standards-principles and infer values from systemic rules, authorities adopt arbitrary interpretations of what the well-being of the child actually entails. It should be stressed that legal principles do not limit the extent of judicial discretion but rather direct its focus. And it is that very focus that ensures the already mentioned judicial freedom ${ }^{24}$. It would be prudent at this point to also evoke the opinion expressed by A. Strzembosz, who considers any judicial decision contrary to the well-being of the child to be erroneous ${ }^{25}$. Hence, a correct interpretation of the provisions of law that duly accounts for the well-being of the child (in the case of the afore evaluation - the well-being of the minor) promotes desirable attitudes and respect for the law, thus constituting the expression of correctly exercised judicial discretion.

In the context of the well-being of the child, judicial discretionary powers are therefore manifested in the ability to duly correlate extra-legal and normative domains. The line (axiological boundary) separating the two domains, i.e. legal axiology and open axiology, is becoming increasingly blurred ${ }^{26}$. Correlations between open axiology and inner systemic axiology stem from the coexistence of standards and clauses pertaining to the same criteria, as well as the creation of legal provisions containing references. The links between the open and inner systemic are rooted not only in the mere coexistence of rules and clauses sharing the same given criterion, but also stem from the entanglement of the axiological well-being of the child in the category of the rights of the child. The criterion itself pertains to the open axiology due to its reference to non-legal values. The strong impact on interpretative activities results from the fact that the well-being of the child is an element of the rule of law, as well as acts of international law and statutory provisions.

\section{ATTEMPT AT OPTIMISATION}

Interpretative discretion of judiciary in the context of the well-being of the child entails judicial freedom of a given case with due consideration for the directions stemming from the very character of the discussed term. In matters pertaining to

${ }^{24}$ See, e.g., judgement of the Supreme Court - Civil Division of 31 January 2018, IV CSK 442/17, Legalis 1765977; judgement of the Supreme Court - Civil Division of 24 November 2016, II CA 1/16, Legalis 1565006; judgement of the Supreme Court - Criminal Division of 29 July 2016, V KK 2/16, Legalis 1508201; judgement of the Supreme Administrative Court of 30 January 2018, I OSK 611/16, Legalis 1740445; judgement of the Supreme Administrative Court of 12 July 2017, II GSK 3611/15, Legalis 1672604; judgement of the Supreme Administrative Court of 30 October 2018, II OSK 1868/16, Legalis 1860297; judgement of the Supreme Administrative Court of 15 October 2010, I OSK 1024/10, Legalis 328643.

25 A. Strzembosz, Nowa ustawa o postępowaniu w sprawach nieletnich. Próba komentarza, Warszawa 1983, p. 50.

${ }^{26}$ L. Leszczyński, Kategoria stuszności w wykładni prawa, „Studia Iuridica Lublinensia” 2011, Vol. 15, p. 52. 
children, the judge adjudicates with the view to shaping the current and postulated situation of the minor/underage person to facilitate their proper development in every aspect thereof, including with respect to their dignity and personal rights. Undoubtedly, due to their age, lack of life experience and knowledge, as well as inability to make informed life decisions, children find themselves at a considerable disadvantage vis-à-vis adult persons and should, therefore, be provided with special protection.

Delimiting the exact scope of judicial discretion is daunting, in my opinion even unfeasible task. It seems that a far more adequate approach would be to employ wording such as narrow or broad perspective when referring to the same. As follows from the afore deliberations, in the context of the well-being of the child, a broad understanding of discretionary powers must be assumed. It is, therefore, vital that an individual approach be adopted to allow verification of the validity of prior determinations. When adjudicating a case in the context of given facts, somewhat different principles apply to correlating the operative interpretation with the general reference clause evoking "the well-being of the child" as compared to the context of legal principles, particularly the principle of protecting the rights of the child, or evoking specific provisions regulating the rights of minors.

One should bear in mind that judicial discretion will pertain to the entire scope of proceedings in the given case, not only to the judgement made. The court is obliged to account for the well-being of the child in the course of courtroom proceedings, e.g. by taking evidence from expert opinions or social enquiry reports. Therefore, the interpretation and determination of the child's current and postulated situation constitutes a problem related not only to direct interpretation of law but also a number of other distinct factors, e.g. psychological, social, or educational which necessitates adequate adjustment of one's approach.

It should be once again emphasized that application of the criterion of the child's well-being must not be perceived in terms of limiting discretionary powers. The child's situation ought to be shaped in such a way so as to eliminate any potential, abstract threats that may emerge in the near future and jeopardise the minor's well-being. At times, strict adherence to the letter of the law proves insufficient as the rights of the child must also be taken into account ${ }^{27}$. The child must not be forced to bear the negative consequences of overly casuistic or imperfectly worded regulations. Hence, judicial discretion ought to be considered in terms of categories such as experience and maturity, as well as values such as objectivism, impartiality, and guardianship over the rule of law, which further emphasizes the key role of the judge in determining and shaping the situation of the child.

${ }^{27}$ See, e.g., judgement of the Supreme Court - Civil Division of 24 November 2016, II CA 1/16, Legalis 1565006. 


\section{REFERENCES}

\section{Literature}

Dyskrecjonalność w prawie, red. W. Staśkiewicz, T. Stawecki, Warszawa 2010.

Galligan D.J., Discretionary Powers. A Legal Study of Official Discretion, New York 2011.

Kołodziejski S., Dobro wspólnych małoletnich dzieci jako przesłanka odmowy orzeczenia rozwodu, „Palestra” 1965, nr 9.

Kozak A., Dylematy prawniczej dyskrecjonalności. Między ideologia polityki a teoria prawa, [in:] Dyskrecjonalność w prawie, red. W. Staśkiewicz, T. Stawecki, Warszawa 2010.

Leszczyński L., Kategoria słuszności w wyktadni prawa, „Studia Iuridica Lublinensia” 2011, Vol. 15.

Leszczyński L., Stosowanie generalnych klauzul odsyłających, Kraków 2001.

Leszczyński L., Tworzenie generalnych klauzul odsyłających, Lublin 2000.

Leszczyński L., Maroń G., Pojęcie i treść zasad prawa oraz generalnych klauzul odsyłajacych. Uwagi porównawcze, „Annales UMCS sectio G (Ius)” 2013, nr 1.

Marciniak J., Treść i sprawowanie opieki nad małoletnim, Warszawa 1975.

Stownik języka polskiego, t. 1: A-K, red. M. Szymczak, Warszawa 1978.

Stownik języka polskiego, t. 2: $L-P$, red. M. Szymczak, Warszawa 1979.

Stownik języka polskiego, t. 3: R-Ż, red. M. Szymczak, Warszawa 1981.

Stelmach J., Dyskrecjonalność sędziowska w pozytywistycznych i niepozytywistycznych koncepcjach prawa, [in:] Dyskrecjonalność w prawie, red. W. Staśkiewicz, T. Stawecki, Warszawa 2010.

Stojanowska W., Dobro dziecka w aspekcie sprawowania nad nim władzy rodzicielskiej, „Studia nad Rodziną" 2000, $\mathrm{nr}$ 4/1(6).

Strzembosz A., Nowa ustawa o postępowaniu w sprawach nieletnich. Próba komentarza, Warszawa 1983.

Wojciechowski B., Dyskrecjonalność sędziowska. Studium teoretycznoprawne, Toruń 2004.

Żyznowski T., [in:] Kodeks postępowania cywilnego, t. 2: Komentarz. Art. 367-729, red. A. Marciniak, K. Piasecki, Warszawa 2016.

\section{Legal acts}

Act of 25 February 1964 - Family and Guardianship Code (Journal of Laws 2019, item 2086). Constitution of the Republic of Poland of 2 April 1997 (Journal of Laws 1997, No. 78, item 483). Convention on the Rights of the Child of 20 October 1989 (Journal of Laws 1991, No. 120, item 526).

\section{Case law}

Judgement of the Constitutional Tribunal of 26 November 2013, P 33/12, Legalis 740186.

Judgement of the Supreme Administrative Court of 15 October 2010, I OSK 1024/10, Legalis 328643. Judgement of the Supreme Administrative Court of 22 June 2017, II OSK 2366/16, Legalis 1649542. Judgement of the Supreme Administrative Court of 12 July 2017, II GSK 3611/15, Legalis 1672604. Judgement of the Supreme Administrative Court of 30 January 2018, I OSK 611/16, Legalis 1740445. Judgement of the Supreme Administrative Court of 30 October 2018, II OSK 1868/16, Legalis 1860297.

Judgement of the Supreme Court - Criminal Division of 18 April 2013, SNO 6/13, Legalis 797136. Judgement of the Supreme Court - Criminal Division of 29 July 2016, V KK 2/16, Legalis 1508201. 
Pobrane z czasopisma Studia Iuridica Lublinensia http://studiaiuridica.umes.pl Data: 26/04/2023 16:33:15

Judgement of the Supreme Court - Civil Division of 24 November 2016, II CA 1/16, Legalis 1565006. Judgement of the Supreme Court - Civil Division of 24 November 2016, III CZP 68/16, Legalis 1533167.

Judgement of the Supreme Court - Civil Division of 31 January 2018, IV CSK 442/17, Legalis 1765977.

Resolution of the Supreme Court - Civil Division of 8 March 2006, III CZP 98/05, Legalis 73542.

Resolution of the Supreme Court - Civil Division of 24 February 2011, III CZP 137/10, Legalis 287414 .

\section{STRESZCZENIE}

Dobro dziecka jest często spotykanym i wspólnym dla wielu gałęzi prawa kryterium. Jest narzędziem zarówno dla prawodawcy, jak i dla podmiotu stosującego prawo, używanym po to, aby ukierunkować podmioty stosujące prawo na obowiązek zapewnienia pełnej ochrony dziecku. W opracowaniu skoncentrowano się na analizie zagadnienia interpretacyjnej dyskrecjonalności sędziowskiej rozpatrywanej w optyce dobra dziecka na przykładzie orzecznictwa Sądu Najwyższego, Naczelnego Sadu Administracyjnego i Trybunału Konstytucyjnego. W pracy została podjęta analiza, jak przejawia się interpretacyjna dyskrecjonalność sędziowska w sprawach, w których głównym wątkiem jest ustalenie aktualnej i postulowanej sytuacji dziecka tak, aby końcowe rozstrzygnięcie było dla niego jak najbardziej korzystne.

Keywords: interpretacyjna dyskrecjonalność sędziowska; dobro dziecka; aksjologia pozaprawna 